\title{
STRATEGI PENGEMBANGAN WIRAUSAHA PEMUDA DALAM MEWUJUDKAN WIRAUSAHAWAN MANDIRI DAN IMPLIKASINYA TERHADAP KETAHANAN EKONOMI KELUARGA (Studi pada Koperasi Sumekar di Kampung Sanggrahan Pathuk Kecamatan Ngampilan Kota Yogyakarta, Daerah Istimewa Yogyakarta)
}

\author{
Lusmino Basia \\ Prodi Ketahanan Nasional Sekolah Pascasarjana \\ Universitas Gadjah Mada \\ Basiajames08.02@gmail.com \\ John Suprihanto \\ Fakultas Ekonomi Universitas Gadjah Mada \\ Armaidy Armawi \\ Fakultas Filsafat Universitas Gadjah Mada
}

\begin{abstract}
Efforts to developed the young entrepreneurs was part of the national policy of youth development. This study aimed to analyzed the development strategy of entrepreneurial youth in realizing the independent entrepreneur in Sanggrahan Village Pathuk District of Ngampilan Yogyakarta, then to analyzed aspects of the constraints that occured during the running of entrepreneurship, the latter to analyzed the economic resilience of family entrepreneurs, in Sanggrahan Village Pathuk District of Ngampilan Yogyakarta.

The method used was merging the descriptive method of qualitative and quantitative methods deskrftif, using structured interviews, questionnaires and literature. Youth development strategy to measured efforts in realizing the independent entrepreneur used seven indicators, in addition to measuring the economic resilience of the families of the young entrepreneurs in Sanggrahan Village Pathuk District of Ngampilan Yogyakarta where two indicators, was used namely income entrepreneurs with minimum wage standards and the family needs of Yogyakarta.

Results of this study showed from 7 indicators of entrepreneurial development strategy in realizing the independent entrepreneur there were three (3) indicators which had not been effectively implemented by the youth, namely leadership, marketing and business legality. These were caused by a lack of resources and capital owned in an effort to developed product marketing and business legality, Indicator development strategy in realizing the independent entrepreneur in the form of motivation and creativity had been done well by the youth, but in terms of competition and market changes still encountered obstacles in the form product pricing efforts that did not refer to the policies set prices government in the form of changes in market prices the increase in fuel prices and electricity tariffs that would be a hindrance youth in becoming independent entrepreneur. From the total number of 36 (thirty six), young entrepreneurs family economic security aspects of revenue was earned by 67 percent and from the aspect of needs was obtained by 66.7 percent. The percentage thus showed that the economic resilience of the families their of the young entrepreneurs in Sanggrahan Village could not considered poor because earn above $U M K$ average to met their primary, secondary, and tertiary needs. It was clearly a portrait of that strategy for
\end{abstract}


Lusmino Basia, John Suprihanto, dan Armaidy Armawi -- Strategi Pengembangan Wirausaha Pemuda Dalam Mewujudkan Wirausahawan Mandiri Dan Implikasinya Terhadap Ketahanan Ekonomi Keluarga (Studi Pada Koperasi Sumekar Di Kampung Sanggrahan Pathuk Kecamatan Ngampilan Kota Yogyakarta

achieving self employment had little impact on the economic resilience of the family but it had implications for the business development of the youth because they had not fully implement the strategy in realizing the independent entrepreneur.

\title{
Keywords: Strategy, Entrepreneurship Independent and Family Economic Resilience
}

\begin{abstract}
ABSTRAK
Upaya mewujudkan wirausahawan muda merupakan bagian dari kebijakan nasional pembangunan kepemudaan. Penelitian ini bertujuan untuk menganalisis strategi pengembangan wirausaha pemuda dalam mewujudkan wirausahawan mandiri di Kampung Sanggrahan Pathuk Kecamatan Ngampilan Yogyakarta, kemudian untuk menganalisis aspek kendala-kendala yang terjadi selama menjalankan wirausaha, yang terakhir untuk menganalisis ketahanan ekonomi keluarga para wirausaha, di Kampung Sanggrahan Pathuk Kecamatan Ngampilan Yogyakarta.

Metode yang digunakan yakni metode penggabungan antara metode deskriptif kualitatif dan metode deskiptif kuantitatif, dengan menggunakan wawancara terstruktur, kuesioner, studi pustaka observasi dan dokumentasi. Untuk mengukur strategi pemuda mengembangkan usaha dalam mewujudkan wirausahawan mandiri digunakan 7 indikator, selain itu guna mengukur ketahanan ekonomi keluarga para wirausahawan muda di Kampung Sanggrahan Pathuk Kecamatan Ngampilan Yogyakarta digunakan 2 indikator yakni, 1) pendapatan para wirausaha dengan standar upah minimum Kota Yogyakarta, dan 2) kebutuhan-kebutuhan keluarga.

Hasil penelitian ini menunjukkan dari 7 indikator strategi pengembangan wirausaha dalam mewujudkan wirausahawan mandiri terdapat 3 (tiga) indikator yang belum dilaksanakan secara efektif oleh para pemuda yaitu kepemimpinan, pemasaran dan legalitas usaha. Hal ini disebabkan oleh kurangnya sumberdaya serta modal yang dimiliki dalam usaha mengembangkan pemasaran produk serta legalitas usaha, indikator strategi pengembangan dalam mewujudkan wirausahawan mandiri berupa motivasi dan kreativitas telah mampu dilakukan baik oleh para pemuda, namun dari segi persaingan usaha dan perubahan pasar masih menemui hambatan berupa penetapan harga produk usaha yang mengacu pada kebijakan harga yang telah ditetapkan pemerintah berupa perubahan harga pasar kenaikan harga bahan bakar minyak dan tarif dasar listrik yang justru menjadi hambatan pemuda dalam mewujudkan wirausahawan mandiri. Dari total wirausahawan muda sejumlah 36 (tiga puluh enam) orang, ketahanan ekonomi keluarga dari aspek pendapatan didapatkan sebesar 67 persen dan dari aspek kebutuhan didapatkan sebesar 66,7 persen. Persentase demikian menunjukkan bahwa ketahanan ekonomi keluarga para pemuda wirausaha di Kampung Sanggrahan dikategorikan tidak miskin karena memperoleh pendapatan di atas UMK rata-rata dan mampu memenuhi kebutuhan primer, sekunder, tersier. Hal ini jelas mengambarkan bahwa strategi dalam mewujudkan wirausaha tidak terlalu berimplikasi terhadap ketahanan ekonomi keluarga namun justru berimplikasi terhadap pengembangan usaha para pemuda karena belum menerapkan strategi penuh dalam mewujudkan wirausahawan mandiri.
\end{abstract}

\section{Kata Kunci: Strategi, Kewirausahaan Mandiri dan Ketahanan Ekonomi Keluarga}

\section{PENGANTAR}

Sektor industri telah membuka banyak lapangan pekerjaan tetapi tetap tidak dapat diingkari adanya kenyataan bahwa tingkat pengangguran di Indonesia masih cukup tinggi. Dampak krisis ekonomi global yang terjadi dewasa ini benar-benar mengguncang perekonomian di negara-negara yang sedang berkembang, termasuk Indonesia, yang belum sepenuhnya bangkit dari krisis moneter yang terjadi di tahun 1997-1998. Kondisi ini sangat memperparah perekonomian di Indonesia. Banyaknya perusahaan besar yang gulung tikar, mengakibatkan sulitnya mencari pekerjaan pada masa sekarang ini. Banyak sekali calon pekerja yang berkeinginan untuk bekerja di instansi pemerintahan atau swasta tetapi lapangan pekerjaan saat ini sangat terbatas, hal ini menyebabkan jumlah pengangguran semakin banyak. Ditinjau 
dari segi masalah pengangguran, ekonomi Indonesia masih merupakan suatu ekonomi negara yang sedang membangun dengan kelebihan tenaga kerja serta banyak masalahmasalah klasik. Selain masalah pengangguran dari masa lalu yang belum terselesaikan, terdapat pula potensi pengangguran pada masa depan yang berasal dari jumlah angkatan kerja baru (Kartasasmita,1996: 63).

Indonesia menghadapi masalah keterbatasan kesempatan kerja bagi para lulusan perguruan tinggi dengan semakin meningkatnyajumlah pengangguran intelektual belakangan ini. Laporan International Labor Organization (ILO) mencatat jumlah pengangguran terbuka pada tahun 2009 di Indonesia berjumlah 9.6 juta jiwa (7.6 persen), dan 10 persen di antaranya adalah sarjana (Nasrun, 2010: 35). Untuk itu Indonesia harus banyak mengembangkan jiwa wirausaha pada masyarakatnya sebagai salah satu cara untuk bisa menopang ketahanan ekonomi bangsa (Setiadi, 2008: 42).

Menurut Wibowo (2011: 19), jumlah wirausahawan muda di Indonesia yang hanya sekitar 0,18 persen dari total penduduk masih tertinggal jauh dibandingkan dengan negaranegara maju seperti Amerika yang mencapai 11,5 persen maupun Singapura yang memiliki 7,2 persen wirausahawan muda dari total penduduknya. Padahal secara konsensus, sebuah negara agar bisa maju, idealnya memiliki wirausahawan sebanyak 5 persen dari total penduduknya yang dapat menjadi keunggulan daya saing bangsa. Dengan menyikapi persaingan dunia bisnis masa kini dan masa depan yang lebih mengandalkan pada knowledge dan intelectual capital, maka agar dapat menjadi daya saing bangsa, pengembangan wirausahawan muda perlu diarahkan pada kelompok orang muda terdidik (intelektual). Pemuda harus perlu didorong dan ditumbuhkan niat mereka untuk berwirausaha (interpreneurial intention).

Berwirausaha membutuhkan strategi yang baik agar tidak mengalami kegagalan namun usaha itu dikatakan sukses dan mandiri. Ada 3 faktor yang wajib diperhatikan mengenai penyebab terjadinya kegagalan, khususnya dalam hal ini bagi pelaku wirausaha UKM, yaitu : (1). Empat puluh lima persen UKM gagal karena kurangnya pemahaman teknik dasar pemasaran (sebenarnya termasuk juga manajemen, yakni manajemen pemasaran). (2). Tiga puluh lima persen gagal karena lemahnya kemampuan manajemen. (3). Dua puluh persen gagal karena terbatasnya sumber dana. Berdasarkan permasalahan tersebut, peneliti melakukan penelitian kewiraswastaan pada Koperasi SUMEKAR di Kampung Sanggrahan Pathuk Kecamatan Ngampilan Kota Yogyakarta, karena sebagian pemuda di kampung ini bemata pencaharian sebagai wirausaha dengan berbagai usaha seperti bakpia pathuk, percetakan, warung makan, dan berbagai jenis usaha minuman. Namun usaha yang mereka jalankan masih banyak menemui kendala. Banyak jumlah pemuda yang berwirausaha di Kampung Sanggrahan Pathuk, tetapi sampai saat ini para wirausaha dalam mengembangkan usahanya belum tercapai dalam mewujudkan wirausahawan mandiri yang berimplikasi terhadap ketahanan ekonomi keluarga.

Penelitian ini dilakukan dengan tujuan unutk :(1). Untuk mengetahui dan menganalisis strategi pengembangan wirausaha pemuda koperasi SUMEKAR di Kampung Sanggrahan Pathuk dalam mewujudkan wirausahawan mandiri. (2). Untuk mengetahui dan 
Lusmino Basia, John Suprihanto, dan Armaidy Armawi -- Strategi Pengembangan Wirausaha Pemuda Dalam Mewujudkan Wirausahawan Mandiri Dan Implikasinya Terhadap Ketahanan Ekonomi Keluarga (Studi Pada Koperasi Sumekar Di Kampung Sanggrahan Pathuk Kecamatan Ngampilan Kota Yogyakarta

menganalisis implikasi strategi pengembangan wirausaha pemuda koperasi SUMEKAR di Kampung Sanggrahan Pathuk dalam upaya mewujudkan wirausahawan mandiri terhadap ketahanan ekonomi keluarga.

Penentuan informan dalam penelitian ini menggunakan pendekatan pupossive sample yaitu dengan sengaja menentukan informan berdasarkan kapabilitas informan dan kebutuhan penelitian. Informan dalam penelitian ini yaitu 2 orang pengurus koperasi SUMEKAR dan 4 orang anggota koperasi SUMEKAR. Penentuan responden dalam penelitian ini digunakan untuk mengetahui strategi pengembangan wirausaha pemuda dalam mewujudkan wirausahawan mandiri dengan menggunakan skala Likert. Sebenarnya ada 64 wirausahawan yang tergabung dalam koperasi SUMEKAR di Kampung Sangrahan Pathuk Kecamatan Ngampilan Kota Yogyakarta, namun dari total populasi yang termasuk sesuai dengan undang-undang kepemudaan pasal 1 ayat 1 nomor 40 tahun 2009 yang berumur maksimal 30 tahun berjumlah 36 orang.

Dalam penelitian ini, pengumpulan data dilakukan dengan metode observasi, wawancara, penyebaran kuesioner dan studi pustaka. Analisis data dalam penelitian ini melalui trianggulasi. Data yang diperoleh peneliti selalu dibandingkan dengan yang lainnya. Demikian juga dengan observasi yang dilakukan peneliti juga dikomparasikan dengan hasil wawancara dan hasil kuesioner (Sugiyono, 2009). Analisis prosentase menggunakan rumus:

$$
\mathrm{P}=\left(\frac{x}{n} 1\right) \times 100
$$

(P: prosentase, $x$ : jumlah jawaban yang benar, $n$ : jumlah seluruh item), dan rumus untuk menentukan ketahanan ekonomi keluarga yaitu: Rata-rata pendapatan per kapita/hari = (Pendapatan KK/30 / jumlah anggota keluarga. Sedangkan untuk perhitungan pengeluaran yaitu: (1) Total pengeluaran perbulan = Jumlah pengeluaran makanan + Jumlah pengeluaran non makanan, (2) Rata-rata pengeluaran per kapita/bulan $=$ Total pengeluaran/jumlah anggota keluarga.

\section{PEMBAHASAN}

Instruksi Presiden No. 4 tahun 1995 tanggal 30 Juni 1995 tentang Gerakan Nasional Memasyarakatkan dan Membudayakan Kewirausahaan, mengamanatkan kepada seluruh masyarakat dan bangsa Indonesia, untuk mengembangkan program-program kewirausahaan. Inpres tersebut dikeluarkan bukan tanpa alasan. Pemerintah menyadari betul bahwa dunia usaha merupakan tulang punggung perekonomian nasional, sehingga harus digenjot sedemikan rupa melalui berbagai departemen teknis maupun institusi-institusi lain yang ada di masyarakat. Melalui gerakan ini pada dasarnya budaya kewirausahaan diharapkan menjadi bagian dari etos kerja masyarakat dan bangsa Indonesia, sehingga dapat melahirkan wirausaha-wirausaha yang baru, handal, tangguh dan mandiri.

\section{Teori Strategi}

Strategi adalah rencana yang disatukan, luas dan berintegrasi yang menghubungkan keunggulan strategis perusahaan dengan tantangan lingkungan, yang dirancang untuk memastikan bahwa tujuan utama dari perusahaan dapat dicapai melalui pelaksanaan yang tepat oleh organisasi (Glueck dan Jauch, 1989: 9). Pengertian strategi dibedakan ke dalam pengertian 
umum dan pengertian khusus. Pengertian umum strategi adalah proses penentuan rencana para pemimpin puncak yang berfokus pada tujuan jangka panjang organisasi, disertai penyusunan suatu cara atau upaya bagaimana agar tujuan tersebut dapat dicapai. Pengertian khusus strategi adalah tindakan yang bersifat inkremental (meningkat) dan terus-menerus, serta dilakukan berdasarkan sudut pandang tentang apa yang diharapkan oleh para pelanggan di masa depan. Dengan demikian, strategi hampir selalu dimulai dari apa yang dapat terjadi dan bukan dimulai dari apa yang terjadi. Terjadinya kecepatan inovasi pasar yang baru dan perubahan pola konsumen memerlukan kompetensi inti (core competencies). Perusahaan perlu mencari kompetensi inti di dalam bisnis yang dilakukan.

\section{Teori Kewirausahaan}

Geoffrey (2000: 6) mengemukakan bahwa para wirausaha adalah orang-orang yang mempunyai kemampuan melihat kesempatankesempatan bisnis; mengumpulkan sumbersumber daya yang dibutuhkan guna mengambil keuntungan dari padanya dan mengambil tindakanyang tepat guna memastikan sukses. Wirausahawan adalah mereka yang melakukan upaya-upaya kreatif dan inovatif dengan jalan mengembangkan ide, meramu sumber daya untuk menemukan peluang (opportunity) dan perbaikan (preparation) hidup. Kewirausahaan (entrepreneurship) muncul apabila seseorang individu berani mengembangkan usaha-usaha dan ide-ide barunya. Proses kewirausahaan meliputi semua fungsi, aktivitas dan tindakan yang berhubungan dengan perolehan peluang dan penciptaan organisasi usaha (Suryana, 2003: 26).
Pengembangan kewirausahaan pemuda merupakan salah satu kegiatan pengembangan potensi keterampilan dan kemandirian berusaha. Kepemudaan dan kewirausahaan merupakan dua hal yang berkaitan tidak dapat dipisahkan. Hal tersebut tercermin dari penjabaran Undang-undang Nomor 40 Tahun 2009 tentang Kepemudaan. Pemerintah banyak mengkaitkan kepemudaan dengan bidang kewirausahaan. Dengan adanya jiwa kewirausahaan di dalam diri pemuda maka jiwa kemandirian pemuda tidak hanya bergantung pada sektor formal namun juga dapat mengembangkan kreativitasnya pada sektor informal seperti kewirausahaan. Wirausaha mandiri dengan demikian menuntut adanya kemandirian. Kemandirian tersebut menunjuk pada adanya kepercayaan akan kemampuan diri untuk menyelesaikan persoalan-persoalan tanpa bantuan khusus dari orang lain, keengganan untuk dikontrol orang lain, dapat melakukan sendiri kegiatan-kegiatan, dan menyelesaikan sendiri masalah-masalah yang dihadapi.

\section{Teori Kepemudaan}

Di dalam Undang-undang Nomor 40 tahun 2009 disebutkan bahwa ketentuan umum pemuda adalah warga Negara Indonesia yang memasuki periode penting pertumbuhan dan perkembangan yang berusia 16 sampai dengan 30 tahun. Kepemudaan adalah bebagai hal yang berkaitan dengan potensi, tanggung jawab, hak, karakter, kapasitas dan cita-cita pemuda. Pembangunan kepemudaan bertujuan untuk mewujudkan pemuda yang beriman dan bertaqwa kepada Tuhan YME, berakhlak mulia, sehat, cerdas, kreatif, inovatif, mandiri, demokratis, bertanggung jawab, berdaya saing, serta memiliki jiwa kepemimpinan, kewirausahaan, kepeloporan, dan kebangsaan 
Lusmino Basia, John Suprihanto, dan Armaidy Armawi -- Strategi Pengembangan Wirausaha Pemuda Dalam Mewujudkan Wirausahawan Mandiri Dan Implikasinya Terhadap Ketahanan Ekonomi Keluarga (Studi Pada Koperasi Sumekar Di Kampung Sanggrahan Pathuk Kecamatan Ngampilan Kota Yogyakarta

berdasarkan Pancasila dan UUD Negara Kesatuan Republik Indonesia tahun 1945.

\section{Teori Ketahanan Ekonomi Keluarga}

Euis (2003: 13) mengatakan bahwa ketahanan keluarga berarti kondisi dinamika sebuah keluarga yang memiliki keuletan dan ketangguhan serta mengandung kemampuan fisik dan material serta psikis dan mental spiritual, guna hidup mandiri mengembangkan diri dan keluarganya untuk hidup harmonis dalam meningkatkan kesejahteraan lahir dan kebahagiaan batin.

Mengacu kepada beberapa konsep di atas, peneliti berpendapat bahwa ketahanan ekonomi keluarga adalah kondisi dinamik suatu keluarga yang berisi keuletan dan ketangguhan yang mengandung kemampuan mengembangkan kekuatan keluarga dalam menghadapi dan mengatasi segala tantangan, ancaman, hambatan serta gangguan yang datang dari luar maupun dalam, yang langsung maupun tidak langsung membahayakan kelangsungan kehidupan ekonomi keluarga. Dewasa ini sedang dikembangkan suatu kebijaksanaan dan strategi pembangunan melalui upaya intervensi dari dalam melalui pemberdayaan keluarga sebagai unit terkecil dari kehidupan bermasyarakat dan bernegara. Hendra (1986: 385) menyebutkan bahwa untuk mengukur perkembangan perekonomian dan kemakmuran Indonesia ada empat komponen yang digunakan yakni kesehatan, pendidikan, pengeluaran perkapita dan pemukiman.

Ketahanan ekonomi diukur dengan jumlah penghasilan atau pengeluaran per rumah tangga dalam jangka waktu tertentu dibandingkan dengan batas kemiskinan. Ketahanan ekonomi keluarga dikatakan kuat dan mampu menghadapi dan mengatasi segala ancaman, tantangan, hambatan dan gangguan serta menjamin kelangsungan perekonomian keluarga. Komponen pertumbuhan ekonomi tidak dapat dilepaskan dari komponen pembagian pendapatan. Pertumbuhan ekonomi tanpa terjadinya proses pembagian pendapatan atau sebaliknya pembagian pendapatan tanpa pertumbuhan ekonomi merupakan sesuatu yang timpang. Aspek pertumbuhan ekonomi merupakan salah satu aspek yang memegang peranan penting bagi indikator pembangunan suatu negara bahkan tidak jarang pertumbuhan ekonomi diidentikkan dengan kesejahteraan dan tingkat kehidupan (Hendra, 1986: 391).

Ketahanan ekonomi keluarga dapat diukur dari tingkat kemiskinan dari keluarga tersebut. Seseorang dapat dikategorikan miskin jika diukur dari pendapatan yang diperoleh kurang atau masih di bawah standar dari UMK yang ditetapkan oleh pemerintah setempat, sedangkan kategori tidak miskin jika pendapatan lebih dari UMK yang sudah ditetapkan. Menurut World Bank (2006: 1-4) definisi kemiskinan dibagi menjadi 3 kategori, yaitu: (1). Kategori sangat miskin yang dapat dilihat dari indikator pendapatan per kapita per hari sebesar kurang dari US \$1; (2). Kategori miskin dilihat dari indikator pendapatan per kapita per hari antara US \$1 sampai US \$2, dan (3). Kategori tidak miskin dilihat dari indikator pendapatan per kapita per hari sebesar lebih dari US \$2.

DI Yogyakarta memiliki upah minimum yang berbeda-beda di masingmasing kabupaten/kotanya. Sebagaimana Surat Keputusan Gubernur DIY Nomor 252/KEP/2014 tentang Upah Minimum Kabupaten/Kota tahun 2015 di Daerah Istimewa Kota Yogyakarta adalah: (1). UMK Kota Yogyakarta Rp. 1.302.500; (2). UMK 
Sleman Rp. 1.200.000; (3). UMK Bantul Rp. 1.163.800; (4). UMK Kulon Progo Rp. 1.138.000; (5). UMK Gunung Kidul Rp. 1.108.249. Dari data tersebut, terlihat bahwa upah minimum paling kecil terdapat di Kabupaten Gunung Kidul.

Di dalam penelitian ini, ketahanan ekonomi keluarga yang diamati adalah dalam hubungannya dengan usaha yang dilakukan oleh pemuda Sanggrahan Pathuk dalam usaha meningkatkan pendapatan keluarga guna terpenuhinya semua kebutuhan keluarga. Jumlah keluarga yang ditanggung dapat juga mempengaruhi status perekonomian seseorang.

\section{Strategi Pengembangan Wirausaha Pemuda Dalam Mewujudkan Wirausahawan Mandiri}

Strategi pengembangan wirausaha pemuda dilakukan dalam beberapa aspek, yaitu:

Pertama, aspek motivasi. Faktor paling dominan yang mendorong terjadinya pendapatan ekonomi masyarakat sedikit adalah lapangan pekerjaan yang ada di Kampung Sanggrahan terbatas, sedangkan sumber daya manusia khususnya keahlian pemuda melimpah. Kondisi ini yang menyebabkan pendapatan pemudanya sedikit dalam memenuhi kebutuhan hidup. Melihat kondisi pengangguran yang semakin meningkat, pemuda di Kampung Sanggrahan mempunyai keinginan unutk meminimalisir pengangguran tersebut dengan menciptakan lapangan pekerjaan di Kampung Sanggrahan Pathuk. Hal ini dimaksudkan agar pemuda yang menganggur mempunyai tambahan penghasilan. Pendapatan lebih ini menjadi makna dasar yang digunakan pemuda untuk berwirausaha. Gambaran aspek motivasi wirausaha juga peneliti amati dari hasil kuesioner. Berikut hasil penelitian berupa data-data dari jawaban responden dan hitungan dengan menggunakan skala Likert, adapun hasilnya sebagai berikut: Jumlah skor ideal untuk seluruh item $=4$ x $108=432$, seandainya semua menjawab sangat setuju (SS). Jumlah yang diperoleh dari penelitian = 365. Jadi berdasarkan data tersebut maka tingkat persetujuan jawaban setuju lebih besar, bahwa pemuda di Kampung Sanggrahan Pathuk selalu termotivasi dalam mewujudkan wirausaha mandiri dengan ingin meningkatkan taraf hidup ekonomi keluarga.

Kedua, aspek kreativitas. Kreativitas merupakan sumber penting dalam penciptaan daya saing untuk semua organisasi yang peduli terhadap growth (pertumbuhan) dan change (perubahan). Syarat-syarat orang yang kreatif, yaitu: (1). Keterbukaan terhadap pengalaman (openness to experience); (2). Pengamatan melihat dengan cara yang biasa dilakukan (observanvce seeing things in unusual ways); (3). Keinginan (curiosity) toleransi terhadap ambiguitas (tolerance of apporites) (4). Kemandirian dalam penilaian, pikiran dan tindakan (independence in judgement, thought and action); (5). Memerlukan dan menerima otonomi (needing and assuming autonomy); (6). Kepercayaan terhadap diri sendiri (self reliance); (7). Tidak sedang tunduk pada pengawasan kelompok (not being subject to group standart and control); (8). Ketersediaan untuk mengambil resiko yang diperhitungkan (willing to take calculated risks) (Frinces, 2004: 34).

Data lain yang diperoleh tentang kreativitas pemuda Kampung Sanggrahan Pathuk dalam mewujudkan wirausahawan 
Lusmino Basia, John Suprihanto, dan Armaidy Armawi -- Strategi Pengembangan Wirausaha Pemuda Dalam Mewujudkan Wirausahawan Mandiri Dan Implikasinya Terhadap Ketahanan Ekonomi Keluarga (Studi Pada Koperasi Sumekar Di Kampung Sanggrahan Pathuk Kecamatan Ngampilan Kota Yogyakarta

mandiri juga peneliti amati dari hasil kuesioner. Berikut hasil penelitian berupa data-data dari jawaban responden dan hitungan, adapun hasilnya sebagai berikut: Jumlah skor ideal = $4 \times 108=432$ seandainya semua menjawab sangat setuju (SS). Jumlah yang diperoleh dari penelitian $=368$. Jadi berdasarkan data tersebut jumlah persetujuan yang menjawab setuju lebih besar, artinya bahwa pemuda Kampung Sanggrahan Pathuk selalu kreatif dalam menjalankan usaha.

Ketiga, aspek kepemimpinan. Di dalam kenyataannya pemimpin dapat mempengaruhi semangat dan kegairahan kerja, keamanan, kualitas kehidupan kerja dan terutama tingkat prestasi suatu organisasi. Para pemimpin juga memainkan peranan kritis dalam membantu kelompok, individu untuk mencapai tujuan. Kepemimpinan yang berhasil menghendaki suatu pengertian yang mendalam terhadap bawahan. Oleh karena itu, Drucker (1979: 26-27), mengatakan bahwa pemimpin sangat perlu mengembangkan beberapa kecakapan, yaitu: (1). Obyektivitas terhadap hubunganhubungan serta perilaku manusia. Maksudnya pemimpin harus memandang bawahan serta perilaku mereka secara obyektif, tanpa berprasangka dan tanpa emosi. (2). Cakap berkomunikasi di dalam perusahaan maupun masyarakat. Maksudnya pemimpin harus mampu berbicara dan menulis secara terus terang serta menyimpulkan dengan teliti pernyataan-pernyataan dari orang lain. Pemimpin harus mudah didekati, mengenal kelompok-kelompok dan pemimpin informalnya, menyeluruh memberitahukan tujuan dan berusaha untuk bekerja sama dengan orang lain. (3). Ketegasan. Maksudnya kemampuan untuk memproyeksikan diri secara mental dan emosional ke dalam posisi seorang pengikut. Kemampuan ini menolong pemimpin untuk memahami pandangan, keyakinan dan tindakan bawahannya. (4). Sadar akan diri sendiri. Maksudnya pemimpin perlu mengetahui kesan apa yang dibuatnya pada orang lain. Pemimpin harus berusaha untuk memenuhi peran yang diharapkan oleh para pengikut. (5). Mengajarkan. Maksudnya pemimpin harus mampu untuk menggunakan kecakapan untuk pedoman, dan pembetulan dalam pemberian petunjuk dengan contohcontoh.

Data lain yang diperoleh tentang kepemimpinan pemuda Kampung Sanggrahan Pathuk dalam mewujudkan wirausahawan mandiri juga peneliti amati dari hasil kuesioner. Berikut hasil penelitian berupa data-data dari jawaban responden dan hitungan, adapun hasilnya sebagai berikut. Jumlah skor ideal untuk seluruh $=4$ x $108=$ 432, seandainya semua menjawab sangat setuju (SS). Jumlah yang diperoleh dari penelitian $=250$. Jadi berdasarkan data tersebut maka mendekati tidak setuju lebih tinggi, atau pemuda Kampung Sanggrahan pathuk dalam kepemimpinan belum masuk kategori baik.

Keempat, aspek pemasaran. Pemasaran produk harus diperhatikan kualitas layanan bagi para konsumen, kualitas layanan bagi konsumen juga dilakukan para wirausaha muda koperasi SUMEKAR di Kampung Sanggrahan Pathuk, karena kualitas merupakan hal yang penting, bahkan pemahaman tentang kualitas sering disalahartikan sebagai sesuatu yang baik, kemewahan, keistimewaan, atau sesuatu yang berbobot. Kualitas layanan mencerminkan perbandingan antara tingkat layanan yang disampaikan perusahaan dibandingkan ekspektasi pelanggan. Kualitas layanan diwujudkan melalui pemenuhan kebutuhan 
dan keinginan pelanggan serta ketepatan penyampaiannya dalam mengimbangi atau melampaui harapan pelanggan. Kualitas dapat dipandang secara luas sebagai keunggulan atau keistimewaan dan dapat didefinisikan sebagai penyampaian layanan yang relatif istmewa terhadap harapan pelanggan. Jika perusahaan melakukan hal yang tidak sesuai dengan harapan pelanggan, berarti perusahaan tersebut tidak memberikan kualitas layanan yang baik. Lovelock (2002: 87) menyatakan bahwa kualitas layanan adalah perspektif konsumen dalam jangka panjang dan merupakan evaluasi kognitif dari transfer jasa.

Pemasaran usaha pemuda Kampung Sanggrahan Pathuk dalam mewujudkan wirausaha mandiri juga peneliti amati dari hasil kuesioner. Berikut hasil penelitian berupa data-data dari jawaban responden dan hitungan. Adapun hasilnya sebagai berikut. Jumlah skor ideal untuk seluruh item $=4$ $\mathrm{x} 108=432$ seandainya semua menjawab sangat setuju (SS). Jumlah yang diperoleh dari penelitian $=187$. Jadi berdasarkan data tersebut maka tingkat persetujuan jawaban sangat tidak setuju, atau pemuda pada Kampung Sanggrahan Pathuk dalam mewujudkan wirausaha mandiri dari aspek pemasaran belum maksimal dalam hal melaksanakan promosi produk yang dijual.

Kelima, aspek persaingan usaha. Undang-Undang No.5 Tahun 1999 tentang Larangan Praktek Monopoli dan Persaingan Usaha Tidak Sehat melarang kesepakatan, aktivitas dan penyalahgunaan dominasi pasar yang dilakukan satu atau beberapa perusahaan. Kesepakatan yang dilarang antara lain termasuk oligopoli, penentuan atau diskriminasi harga, predatory pricing, pembagian pasar, group boycots, kartel, perserikatan antar perusahaan, oligopsoni, vertical integration, exclusive dealing dan perjanjian dengan pihak asing yang dapat mengakibatkan praktek usaha tidak sehat. Aktivitas yang dilarang antara lain monopoli, monopsoni, market control, predatory pricing, persekongkolan dalam penawaran dan mendapatkan rahasia pesaing. Dalam hal ini, Komisi Pengawas dan Persaingan Usaha (KPPU) yang diresmikan pada tanggal 7 Juni 2000 dibentuk sebagai implementasi dari Undang-undang No. 5 Tahun 1999 tentang Larangan Praktek Monopoli dan Persaingan Usaha Tidak Sehat. Lembaga ini berfungsi memeriksa berbagai pihak yang diduga melanggar undang-undang tersebut, memberi putusan dan menjatuhkan sangsi kepada para pelaku usaha yang terbukti melanggar.

Data lain yang diperoleh tentang persaingan usaha pemuda Kampung Sanggrahan Pathuk dalam mewujudkan wirausahawan mandiri juga peneliti amati dari hasil kuesioner. Berikut hasil penelitian berupa data-data dari jawaban responden dan hitungan, adapun hasilnya sebagai berikut. Jumlah skor ideal untuk seluruh item $=4$ $\mathrm{x} 108=432$, seandainya semua menjawab sangat setuju (SS). Jumlah yang diperoleh dari penelitian $=331$. Jadi berdasarkan data tersebut maka tingkat persetujuan mendekati setuju, atau diketahui pemuda dalam mewujudkan wirausaha mandiri banyak pesaing usaha yang lain, dan selalu menggunakan cara yang tidak sportif dalam menghadapi kompetitor yang mempunyai usaha seperti yang mereka jalankan.

Keenam, aspek legalitas usaha. Kasus yang terjadi di UKM, banyak yang sering lupa atau menganggap tidak penting atau penting, tetapi tidak menjadi prioritas untuk membuat 
Lusmino Basia, John Suprihanto, dan Armaidy Armawi -- Strategi Pengembangan Wirausaha Pemuda Dalam Mewujudkan Wirausahawan Mandiri Dan Implikasinya Terhadap Ketahanan Ekonomi Keluarga (Studi Pada Koperasi Sumekar Di Kampung Sanggrahan Pathuk Kecamatan Ngampilan Kota Yogyakarta

kesepakatan/perjanjian tertulis, karena adanya "trust" (saling percaya). Masalah utamanya adalah ketika perusahaan berkembang dan span of control masing-masing sudah terlalu luas (harus menangani banyak hal), rentan akan timbul kesalahpahaman jika tidak ada rujukan dan pedoman tertulis untuk menghindarinya. Potensi konflik yang biasa terjadi seringkali timbul terkait pengambilan keputusan tertentu, adanya intervensi atau tumpang tindih (overlapping) tugas, serta pembagian tugas dan tanggung jawab dalam manajemen. Pada kebanyakan UKM, pemilik (pemegang saham) juga terlibat aktif dalam manajemen (pengurusan perseroan) perusahaan tersebut, baik itu sebagai persero aktif (direksi) atau persero pasif (komisaris) (Priyono dan Husin, 2014: 53-55). Hal ini terjadi juga pada wirausaha di Kampung Sanggrahan Pathuk saat memulai usaha, bersinggungan dengan banyak aspek hukum lainnya, misalnya; (1). Izin prinsip: permodalan dan perizinan hukum aturan investasi, badan usaha, (2). Izin operasional: izin produksi, izin edar/ perdagangan, dll, (3). Pemekerjaan (hukum ketenagakerjaan), 4) Pajak (hukum/aturan perpajakan), (4). Perlindungan merek dagang atau hak cipta (hukum atau aturan mengenai hak atas kekayaan intelektual - HAKI), (5). Pengajuan/permohonan kredit perbankan, (6). Keikutsertaan tender, (7). Standar produk dari aspek kesehatan (BPOM), halal (MUI), izin industri rumah tangga (PIRT), dan sebagainya.

Gambaran pemuda dalam mewujudkan wirausaha mandiri dalam aspek legalitas usaha juga dapat diamati dari kuesioner. Berikut hasil penelitian berupa data-data jawaban responden dan hitungan dengan hitungannya sebagai berikut. Jumlah skor ideal $=4 \times 108$
= 432, seandainya semua menjawab sangat setuju (SS), jumlah yang diperoleh dari penelitian $=242$. Jadi berdasarkan data tersebut maka tingkat persetujuan mendekati jawaban tidak setuju, atau sebagian besar pemuda yang mewujudkan wirausaha mandiri belum menganggap penting mempunyai legalitas usaha dalam usaha dijalankan. Starategi pemuda Kampung Sanggrahan Pathuk salah satunya dalam mendapatkan legalitas usaha masih belum dikatakan baik.

Ketujuh, aspek perubahan pasar. Perubahan nilai tukar rupiah, kenaikan harga bahan bakar minyak, dan kenaikan tarif dasar listrik ini sangat berpengaruh secara nyata terhadap kondisi perekonomian nasional yang pada akhirnya berdampak langsung ataupun tidak langsung pada kegiatan usaha UKM (Usaha Kecil Menengah). Kebijakan pasar bebas Asia atau AFTA (Asean Free Trade Area) berpengaruh terhadap persaingan pasar domestik dengan produsen dari negaranegar Asia. Tantangan yang dihadapi oleh UKM yang saat ini tumbuh secara tradisional bersaing dalam pasar bebas dengan UKM atau bahkan produsen dari mancanegara. Untuk menghadapi kondisi yang semakin kompleks, tentunya UKM yang unggul dalam persaingan adalah UKM yang memiliki, pertama, kemampuan dalam memenuhi kebutuhan konsumen secara tepat, tepat dengan harga yang terjangkau, serta variasi produk dan layanan yang beragam; kedua, manajemen yang selalu berkembang sehingga mampu mengatasi tingkat kerumitan dan perubahan yang terjadi setiap saat (Priyono dan Husin, 2014: 33).

Data lain yang diperoleh dari aspek perubahan pasar/ekonomi nasional dalam mewujudkan wirausahawan mandiri juga 
peneliti amati dari hasil kuesioner. Berikut hasil penelitian berupa data-data dari jawaban responden dan hitungan, adapun hasilnya sebagai berikut. Jumlah skor ideal untuk seluruh item $=4$ x $108=432$, seandainya semua menjawab sangat setuju (SS). Jumlah yang diperoleh dari penelitian $=341$. Jadi berdasarkan data tersebut maka tingkat persetujuan mendekati jawaban setuju, atau strategi pemuda Kampung Sanggrahan Pathuk dalam mewujudkan wirausaha mandiri sangat ditentukan oleh kebijakan perubahan pasar, misalnya ketika kenaikan harga BBM atau tarif dasar listrik yang selalu berubah-ubah. Kebijakan perubahan harga pasar kemudian yang menjadi kendala besar dalam strategi pengembangan usaha. Para pemuda terjebak dengan kebijakan harga yang diputuskan pemerintah sehingga mereka sendiri kesulitan menentukan harga produk usaha.

\section{Kendala-Kendala Dalam Mewujudkan Wirausahawan Mandiri}

Terdapat 4 kendala yang dihadapi para wirausahawan di Kampung Sanggrahan Pathuk. Selengkapnya diuraikan di bawah ini.

Pertama, kurangnya pemahaman teknik pemasaran, para wirausaha di Kampung Sanggrahan Pathuk banyak yang tidak mengerti bagaimana menerapkan strategi pemasaran, disebabkan tingkat pendidikan mereka yang masih di bawah rata-rata, kurang memahami ilmu tentang pemasaran.

Kedua, legalitas usaha masih bermasalah, wirausaha muda mandiri di Kampung Sanggrahan Pathuk mayoritas belum memiliki surat-surat izin usaha, dengan berbagai alasan untuk tidak mengurusnya, seperti pengurusan HO (Izin Gangguan) sesuai dengan Peraturan
Daerah No. 2 Tahun 2005 tentang Izin Gangguan yang salah satu persyaratanya, harus mempunyai akta tanah usaha, sedangkan tempat usaha mereka belum sepenuhnya milik mereka, karena masih sistem sewa (indung) bangunan dan surat-surat izin yang lainnya masih belum ada, dan juga pengurusan izin MUI (Majelis Ulama Indonesia) Yogyakarta, bagi yang beragama Kristen/non muslim tidak semudah bagi yang beragama muslim dalam mengurus sertifikat MUI, dan biaya seritifikat halal dari MUI berkisar Rp 2.000.000 (Dua juta rupiah) sampai Rp 4.500.000 (Empat juta limaratus ribu rupiah) per jenis produk dan jika mempunyai merek dagang dikenakan biaya Rp 100.000 (Seratus ribu rupiah), jika 2 jenis produk yang dihasilkan, biaya yang dikeluarkan sekitar Rp 9.000.000 (Sembilan juta rupiah), dan berlaku dua tahun, setiap 6 bulan sekali terjadi pengecekan di tempat produksi, ini dikenakan biaya dalam setiap pengecekan, dalam hal pengurusan sertifikat halal memang membutuhkan biaya yang banyak, ini juga yang menjadi kendala bagi para wirausaha muda, walaupun bahan baku yang dipakai sudah diperiksa oleh BPOM (Badan Pengawas Obat dan Makanan), bahan baku produksi bagi yang usaha makanan sudah termasuk kategori halal.

Ketiga, penerapan sistem kepemimpinan yang belum baik, kepemimpinan yang dilakukan para pemuda wirausaha pada Kampung Sangrahan Pathuk dalam memimpin usaha masih dikatakan gagal. Gagalnya kepemimpinan wirausaha muda mandiri di Kampung Sanggrahan Pathuk disebabkan oleh kurangnya pengetahuan pendidikan kepemimpinan, kurangnya kerja sama antara wirausaha dengan pemerintah, ataupun pihak swasta tentang pendidikan, pelatihan 
Lusmino Basia, John Suprihanto, dan Armaidy Armawi -- Strategi Pengembangan Wirausaha Pemuda Dalam Mewujudkan Wirausahawan Mandiri Dan Implikasinya Terhadap Ketahanan Ekonomi Keluarga (Studi Pada Koperasi Sumekar Di Kampung Sanggrahan Pathuk Kecamatan Ngampilan Kota Yogyakarta

yang dilakukan oleh pemerintah dalam hal pendidikan kepemimpinan.

Keempat, kurangnya modal dan dukungan pemerintah, permasalahan modal adalah masalah klasik yang sering dianggap suatu kendala dalam pengembangan bisnis/ usahadi kalangan entrepreneur. Kredit Usaha Rakyat (KUR) dan program PNPM merupakan angin segar bagi para wirausawaan saat ini, namun yang perlu mendapat perhatian tentang regulasinya.Termasuk juga dana CSR. Modal tidak hanya uang. Dalam kacamata para wirausawaan modal adalah sesuatu yang dapat digunakan untuk menjalankan usaha. Dengan demikian modal dapat berupa benda fisik atau pun bukan. Pikiran, kesempatan, waktu, pendidikan dan pengalaman merupakan benda abstrak yang sesungguhnya merupakan modal yang tidak ternilai dan sangat menentukan keberhasilan dalam kewirausahaan (Tambunan, 2009: 46). Bagi para Wirausahawan Muda Mandiri di Kampung Sanggrahan Pathuk, hal mendapatkan tambahan modal dan dukungan pemerintah masih kurang, ini yang menjadi kendala para wirausaha di Kampung Sanggrahan Pathuk hingga sekarang ini. Para wirausaha dalam menjalankan usaha untuk mengurus kredit ke bank, persyaratannya yang didapat susah untuk dipenuhi, dengan berbagai alasan dari pihak bank yang terlalu birokratik.

\section{Implikasinya Terhadap Ketahanan Ekonomi Keluarga}

\section{Parameter Ketahanan Ekonomi Keluarga}

Paremeter yang digunakan dalam penelitian ini adalah ketahanan ekonomi keluarga yang mengacu pada pemenuhan kebutuhan fisik (physiological needs), yang merupakan kebutuhan dasar yang harus dipenuhi oleh suatu keluarga. Dalam melihat keadaan dan kemampuan keluarga mencukupi kebutuhan dasar yaitu sandang, pangan dan papan digunakan perbandingan antara pendapatan yang diperoleh dari hasil wirausaha. Di antara standar kemiskinan yang sudah ada seperti standar bank dunia, standar kemiskinan dari BPS, maupun standar dari Sajogyo, standar yang sesuai dan tepat diterapkan di DIY adalah standar UMK (Upah Minimum Kabupaten/Kota) yang ditetapkan oleh Gubernur DIY. Adapun UMK yang ditetapkan oleh pemerintah DIY berbeda untuk setiap kabupaten maupun kota.

Meskipun demikian tidak dapat dipungkiri bahwa besarnya pendapatan yang diperoleh yang dilakukan oleh keluarga tidak selalu menggambarkan kemiskinan maupun kekayaan suatu keluarga. Hal ini dikarenakan kemiskinan memiliki pengertian yang luas dan tidak mudah untuk mengukurnya. Setidaknya, terdapat 2 macam ukuran kemiskinan yang dapat menjadi rujukan, yaitu kemiskinan absolut dan kemiskinan relatif. Pada dasarnya kemiskinan dikaitkan dengan perkiraan tingkat pendapatan dan kebutuhan dimana perkiraan kebutuhan tersebut hanya dibatasi pada kebutuhan pokok sebagai kebutuhan minimum yang memungkinkan seorang dapat hidup secara layak. Apabila pendapatan tidak dapat memenuhi kebutuhan minimum maka seorang dapat dikatakan miskin.Tingkat pendapatan minimum merupakan pembatas antara keadaan miskin dan tidak miskin yang sering disebut sebagai garis batas kemiskinan. Konsep ini dikenal sebagai konsep kemiskinan absolut. Konsep tersebut dimaksudkan untuk menentukan tingkat pendapatan minimum yang cukup untuk memenuhi kebutuhan fisik terhadap makanan, pakaian perumahan untuk 
menjamin kelangsungan hidup. Namun di sisi lain penentuan garis kemiskinan secara objektif sulit dilaksanakan karena banyak faktor yang mempengaruhinya. Oleh sebab itu, maka garis kemiskinan berbeda antara satu tempat dengan tempat lainnya sehingga tidak ada satu garis kemiskinan yang berlaku yang berlaku umum (Wibowo, 2011: 83).

Di sisi lain orang yang memiliki pendapatan yang dapat memenuhi kebutuhan dasar minimum tidak selalu berarti tidak miskin. Ada ahli yang berpendapat bahwa walaupun pendapatan sudah mencapai tingkat kebutuhan dasar minimum tapi masih jauh lebih rendah dibandingkan keadaan masyarakat di sekitarnya maka orang tersebut masih masuk dalam kategori miskin. Ini terjadi karena kemiskinan lebih banyak ditentukan oleh keadaan sekitarnya daripada lingkungan orang yang bersangkutan. Oleh sebab itu, maka konsep kemiskinan relatif bersifat dinamis, sehingga kemiskinan akan selalu ada. Badan Pusat Statistik (BPS) menggunakan pendekatan pemenuhan kebutuhan dasar (basic needs approach) dalam menentukan kemiskinan di Indonesia. Seseorang tergolong dalam kategori miskin bila ia tidak mampu memenuhi kebutuhan dasarnya (basic needs) (BPS: 2015) Dengan kata lain, kemiskinan dipandang sebagai ketidakmampuan dari sisi ekonomi dalam memenuhi kebutuhan dasar, baik makanan maupun non makanan yang diukur dari sisi pengeluaran. Hendra (1986: 385) menyebutkan bahwa ketahanan ekonomi diukur dengan jumlah penghasilan atau pengeluaran per rumah tangga dalam jangka waktu tertentu dibandingkan dengan batas kemiskinan. Ketahanan ekonomi keluarga dikatakan kuat jika mampu menghadapi dan mengatasi segala ancaman, tantangan, hambatan dan gangguan serta menjamin kelangsungan perekonomian keluarga.

Secara luas, miskin dapat diartikan sebagai ketidakmampuan seseorang atau keluarga dalam memenuhi kebutuhannya, mencakup kebutuhan ekonomi, sosial, politik, emosional maupun spiritual. Pengertian ini memang terlalu luas dan tidak operasional sehingga sulit untuk diukur. Oleh karena itu, pengertian miskin itu biasanya dipersempit hanya miskin secara ekonomi. Di Indonesia, pengertian ini dipersempit lagi sebagai ketidakmampuan dalam memenuhi kebutuhan pokok atau kebutuhan dasar berupa kebutuhan pangan dan non pangan.

\section{Pendekatan Pendapatan}

Seseorang dikatakan miskin jika diukur dari pendapatan yang diperoleh kurang dari atau masih di bawah standar UMK yang ditetapkan oleh pemerintah setempat. Sedangkan kategori tidak miskin jika pendapatan lebih dari UMK (Upah Minimum Kota), yang sudah ditetapkan. Pendapatan diukur menggunakan skala Likert, data yang dihimpun tentang pendapatan juga peneliti amati dari hasil kuesioner. Jumlah skor ideal untuk seluruh item 4 x $108=432$, seandainya semua menjawab sangat setuju (SS). Jumlah yang diperoleh dari penelitian = 341. Jadi berdasarkan data tersebut maka tingkat persetujuan mendekati setuju, pemuda dalam mewujudkan wirausaha mandiri, aspek pendapatan dalam mewujudkan wirausahawan mandiri melebihi pendapatan sebagai karyawan yang mendapatkan UMK (Upah Minimum Kota Yogyakarta ). Berarti dikategorikan tidak miskin atau ketahanan ekonominya baik. 
Lusmino Basia, John Suprihanto, dan Armaidy Armawi -- Strategi Pengembangan Wirausaha Pemuda Dalam Mewujudkan Wirausahawan Mandiri Dan Implikasinya Terhadap Ketahanan Ekonomi Keluarga (Studi Pada Koperasi Sumekar Di Kampung Sanggrahan Pathuk Kecamatan Ngampilan Kota Yogyakarta

\section{Pendekatan Kebutuhan}

Mengukur ketahanan ekonomi pemuda Kampung Sanggahan Pathuk dalam mewujudkan wirausaha mandiri, dilihat dari tingkat pemenuhan kebutuhan dari penghasilan yang mereka yang dapat, ini berdasarkan pada standar di Indonesia, yaitu menurut BPS menggunakan konsep kemampuan memenuhi kebutuhan dasar (basic need approach) (BPS: 2015). Dengan pendekatan ini, kemiskinan dipandang sebagai ketidakmampuan dari sisi ekonomi untuk memenuhi kebutuhan dasar makanan dan bukan makanan yang diukur dari sisi pengeluaran. Dengan kata lain, kemiskinan dipandang sebagai ketidakmampuan dari sisi ekonomi untuk memenuhi kebutuhan makanan maupun non makanan yang bersifat mendasar. Penduduk miskin adalah penduduk yang memiliki rata-rata pengeluaran per kapita per bulan di bawah garis kemiskinan.

Pengukuran kemiskinan dengan menggunakan konsep kemampuan memenuhi kebutuhan dasar (basic need approach) tidak hanya digunakan oleh BPS, tetapi juga oleh negara-negara lain, seperti Armenia, Senegal, Pakistan, Bangladesh, Vietnam, Sierra Leone, dan Gambia. Data kebutuhan juga peneliti amati dari hasil kuesioner. Berikut hasil penelitian berupa data-data dari jawaban responden dan hitungan dengan menggunakan skala Likert, adapun hasilnya sebagai berikut. Jumlah skor ideal untuk seluruh item $=4$ $\mathrm{x} 108=$ 432, seandainya semua menjawab sangat setuju (SS). Jumlah yang diperoleh dari penelitian $=341$. Jadi berdasarkan data tersebut maka tingkat persetujuan mendekati jawaban setuju, untuk memenuhi kebutuhan hidup sehari-hari melebihi UMK (Upah Minimum Kabapaten/Kota) yang menjadi patokan pendapatan, dan mereka bisa memenuhi kebutuhan sekunder sampai kebutuhan tersier. Hal ini menyimpulkan pemuda yang mewujudkan wirausahawan mandiri tergolong tidak miskin.

\section{Kewirausahaan Mandiri Dalam Mewujudkan Ketahanan Ekonomi Keluarga}

Suhardjo (1989: 34) mengemukakan bahwa pendapatan suatu keluarga sangat berpengaruh terhadap alokasi pengeluaran keluarga tersebut. Oleh karena itu, besar kemungkinan bahwa semakin besar pendapatan yang diperoleh suatu keluarga maka semakin besar pula pengeluaran keluarga tersebut. Tingkat ketahanan ekonomi suatu keluarga dapat dilihat dari besar kecilnya pendapatan keluarga tersebut melalui pendekatan terhadap besar kecilnya pengeluaran total keluarga. Data rata-rata pendapatan per bulan yang peneliti peroleh dari informan sebagai wirausaha baik mereka yang menjalankan usaha percetakan, sembako, usaha pembuatan bakpia, warung kios, minuman dan warung makan adalah sebagai berikut, dari total responden sebanyak 36 orang rata-rata pendapatan dari hasil wirausaha Rp. 5.088.888,89 (Lima juta delapan puluh delapan ribu delapan ratus delapan puluh delapan koma delapan puluh sembilan rupiah) Perhitunganya adalah sebagai berikut: (1). Rata-rata pendapatan per kapita/hari = (pendapatan wirausaha / 30 / Jumlah anggota keluarga). (2). Kondisi tahan (Rata-rata pendapatan per kapita per hari >1,5 USD). (3). Kondisi tidak tahan (Rata-rata pendapatan per kapita per hari < 1,5 USD). Dengan menggunakan standar untuk hidup layak minimal pendapatan per kapita per hari 1,5 USD atau Rp. 20.400 (Dua puluh ribu empat ratus rupiah) (1 USD 
= Rp. 13.600 (Tigabelas ribu enamratus rupiah), dengan indikator pendapatan per kapita per hari 1 USD atau sekitar Rp.13.600 jika dihitung dalam rata-rata keseluruhan dengan anggota keluarganya berjumlah 4 orang yang dalam perhitungannya adalah $\mathrm{Rp}$ 5.088.888,89/30/4 = Rp. 42.407 (Empat puluh dua ribu empatratus tujuh rupiah), maka pemuda wirausaha Kampung Sanggrahan Pathuk Kecamatan Ngampilan Yogyakarta dalam kategori layak atau tidak miskin.

Jika dihitung juga dengan menggunakan konversi pendapatan pemuda wirausaha terhadap UMK Kota Yogyakarta, menunjukkan kondisi pendapatan para responden wirausaha pemuda Kampung Sanggrahan Pathuk Kecamatan Ngampilan Yogyakarta, ratarata penghasilan responden sebesar Rp. 5.088.888,89 (Lima Juta delapan puluh delapan ribu delapan ratus delapan puluh delapan koma delapan puluh sembilan rupiah) melebihi jumlah UMK Kota Yogyakarta, sebesar Rp. 1. 302.500 (Satu juta tigaratus dua ribu limaratus rupiah). Semua anggota wirausaha Kampung Sangrahan Pathuk termasuk kategori tahan atau tidak miskin. Pendapatan hasil wirausaha digabungkan telah memberikan kontribusi yang cukup besar, karena dari usaha tersebut dapat memberikan kontribusi pada pendapatan total keluarga dalam pemenuhan kebutuhan keluarga. Dapat diketahui ternyata pendapatan yang diperoleh dari pendapatan dari berwirausaha dari semua macam jenis wirausaha yang dijalankan oleh para pemuda Kampung Sanggrahan Pathuk mampu meningkatkan ketahanan ekonomi keluarga.

Jika dilihat dari kebutuhan hidup pemuda wirausaha, BPS menyatakan kategori pengeluaran adalah makanan, perumahan, pakaian, barang jasa dan pengeluaran non konsumsi seperti untuk usaha dan lain-lain pembayaran. Secara terperinci pengeluaran konsumsi adalah semua pengeluaran untuk makanan, minuman pakaian, pesta atau upacara, barang-barang lama dan lain-lain yang dilakukan oleh setiap anggota rumah tangga baik itu di dalam maupun di luar rumah, baik keperluan pribadi maupun keperluan rumah tangga (BPS, 2007). Kebutuhan pokok sebagai kebutuhan esensial sedapat mungkin harus terpenuhi oleh suatu rumah tangga supaya mereka dapat hidup wajar. Kebutuhan esensial ini yaitu: makanan, pakaian, perumahan, kesehatan, pendidikan, transportasi, perawatan pribadi, rekreasi. Alokasi pengeluaran konsumsi masyarakat secara garis besar dapat digolongan dalam 2 kelompok penggunaan, yaitu pengeluaran untuk makanan dan pengeluaran bukan untuk makanan. Di samping itu, terjadi peningkatan garis kemiskinan sebagai akibat dari peningkatan biaya yang harus dibayar keluarga golongan bawah untuk memenuhi standar minimum kebutuhan dalam hal pangan dan non pangan, berikut perhitungan pengeluaran keluarga: (1). Total pengeluaran per bulan $=$ jumlah pengeluaran makanan + jumlah pengeluaran non makanan. (2). Ratarata pengeluaran per kapita per bulan $=$ Total pengeluaran / jumlah anggota keluarga.

Pengeluaran keluarga wirausaha pemuda Kampung Sanggrahan Pathuk Kecamatan Ngampilan Yogyakarta yang paling besar adalah pengeluaran makanan rata-rata sebesar Rp. 1.297.500 (Satu juta dua ratus sembilan puluh tujuh ribu limaratus rupiah) atau sekitar 60 persen, sedangkan pengeluaran non makanan rata-rata sebesar Rp. 862.778 (Delapan ratus enam puluh dua ribu tujuh 
Lusmino Basia, John Suprihanto, dan Armaidy Armawi -- Strategi Pengembangan Wirausaha Pemuda Dalam Mewujudkan Wirausahawan Mandiri Dan Implikasinya Terhadap Ketahanan Ekonomi Keluarga (Studi Pada Koperasi Sumekar Di Kampung Sanggrahan Pathuk Kecamatan Ngampilan Kota Yogyakarta

ratus tujuh puluh delapan ribu rupiah) atau sekitar 40 persen. Rata-rata pengeluaran dari total responden adalah sebesar Rp. 2.160.278 (Dua juta seratus enampuluh ribu duaratus tujuh puluh delapan rupiah), dan didapat pengeluaran per kapitanya jika

Tabel 1

Selisih Pendapatan dan Pengeluaran Pemuda Wirausaha pada koperasi SUMEKAR Kampung Sanggrahan Pathuk

\begin{tabular}{|c|c|c|c|c|}
\hline No & $\begin{array}{c}\text { Total } \\
\text { Pendapatan/ } \\
\text { bln (Rp) }\end{array}$ & $\begin{array}{c}\text { Total } \\
\text { Pengeluaran/ } \\
\text { bln (Rp) }\end{array}$ & $\begin{array}{c}\text { Jml } \\
\text { Anggota } \\
\text { Keluarga }\end{array}$ & $\begin{array}{c}\text { Selisih } \\
\text { (Rp) }\end{array}$ \\
\hline 1 & 7.000 .000 & 2.950 .000 & 5 & 4.050 .000 \\
\hline 2 & 5.000 .000 & 2.600 .000 & 4 & 2.400 .000 \\
\hline 3 & 7.500 .000 & 3.030 .000 & 3 & 4.470 .000 \\
\hline 4 & 8.000 .000 & 2.630 .000 & 4 & 5.370 .000 \\
\hline 5 & 8.500 .000 & 3.000 .000 & 4 & 5.500 .000 \\
\hline 6 & 5.000 .000 & 2.500 .000 & 3 & 2.500 .000 \\
\hline 7 & 5.500 .000 & 2.660 .000 & 3 & 2.840 .000 \\
\hline 8 & 2.500 .000 & 1.300 .000 & 3 & 1.200 .000 \\
\hline 9 & 4.500 .000 & 1.800 .000 & 4 & 2.700 .000 \\
\hline 10 & 8.500 .000 & 2.900 .000 & 3 & 5.600 .000 \\
\hline 11 & 5.000 .000 & 2.250 .000 & 4 & 2.750 .000 \\
\hline 12 & 5.200 .000 & 2.350 .000 & 3 & 2.850 .000 \\
\hline 13 & 3.600 .000 & 1.250 .000 & 3 & 2.350 .000 \\
\hline 14 & 5.400 .000 & 2.800 .000 & 3 & 2.600 .000 \\
\hline 15 & 6.400 .000 & 2.850 .000 & 4 & 3.600 .000 \\
\hline 16 & 3.700 .000 & 1.350 .000 & 4 & 2.350 .000 \\
\hline 17 & 2.700 .000 & 1.250 .000 & 2 & 1.450 .000 \\
\hline 18 & 3.400 .000 & 1.250 .000 & 4 & 2.150 .000 \\
\hline 19 & 5.000 .000 & 2.400 .000 & 6 & 2.600 .000 \\
\hline 20 & 9.200 .000 & 3.250 .000 & 5 & 5.950 .000 \\
\hline 21 & 6.000 .000 & 2.790 .000 & 5 & 3.210 .000 \\
\hline 22 & 4.300.000 & 2.460 .000 & 4 & 1.840 .000 \\
\hline 23 & 3.700 .000 & 1.420 .000 & 4 & 2.280 .000 \\
\hline 24 & 3.500 .000 & 1.330 .000 & 3 & 2.170 .000 \\
\hline 25 & 4.000 .000 & 1.660 .000 & 4 & 2.340 .000 \\
\hline 26 & 5.000 .000 & 2.400 .000 & 5 & 2.600 .000 \\
\hline 27 & 5.300 .000 & 2.170 .000 & 4 & 3.130 .000 \\
\hline 28 & 4.800 .000 & 1.430 .000 & 3 & 3.370 .000 \\
\hline 29 & 3.600 .000 & 1.200 .000 & 4 & 2.400 .000 \\
\hline 30 & 4.300.000 & 2.150 .000 & 4 & 2.150 .000 \\
\hline 31 & 2.700 .000 & 1.150 .000 & 3 & 1.550 .000 \\
\hline 32 & 4.200 .000 & 2.020 .000 & 3 & 2.180 .000 \\
\hline 33 & 5.400 .000 & 2.580 .000 & 4 & 2.820 .000 \\
\hline 34 & 6.700 .000 & 2.810 .000 & 5 & 3.890 .000 \\
\hline 35 & 3.800 .000 & 1.490 .000 & 3 & 2.310 .000 \\
\hline 36 & 5.700 .000 & 2.340 .000 & 5 & 3.360 .000 \\
\hline
\end{tabular}

Sumber: Data Primer 2015 (diolah) rata-rata para responden memiliki keluarga sebanyak 4 orang, perhitungannya adalah total pengeluaran per bulan dibagi jumlah anggota keluarganya: RP 2.160.278/4 = Rp. 540.069,5 (Limaratus empat puluh ribu enampuluh sembilan koma lima rupiah).

Sedangkan untuk pengeluaran, Badan Pusat Statistika (BPS) mematok pengeluaran minimal per kapita per bulan yang disebut dengan batas kemiskinan. rata-rata pengeluaran dari total responden adalah Rp. 2.160.278 (Dua juta seratus enam puluh ribu dua ratus tujuh puluh delapan rupiah) dan didapat pengeluaran per kapitanya jika rata-rata para responden memiliki jumlah anggota keluarga sebanyak 4 orang. Perhitungannya adalah total pengeluaran per bulan dibagi jumlah anggota keluarga; 2.160.278/4 = Rp.540.069,5 (Lima ratus empat puluh ribu enam puluh sembilan koma lima rupiah) sedangkan untuk garis kemiskinan Kota Yogyakarta tahun 2015 sebesar Rp. 312.056,00 (Tiga ratus dua belas ribu lima puluh enam rupiah) (BPS, 2015), sehingga pemuda yang berwirausaha di Kampung Sanggrahan Pathuk Kecamatan Ngampilan Yogyakarta masuk dalam kategori keluarga tahan atau tidak miskin.

Sedangkan untuk mengetahui selisih rata-rata pendapatan per bulan dan pengeluaran pemuda wirausaha Kampung Sanggrahan Pathuk Kecamatan Ngampilan Yogyakarta dapat dilihat pada tabel 1.

\section{SIMPULAN}

Berdasarkan uraian tersebut di atas dapat ditarik simpulan sebagai berikut:

Pertama, strategi pengembangan wirausaha pemuda dalam mewujudkan wirausahawan mandiri, pada aspek motivasi, kreativitas persaingan usaha sudah dijalankan 
dengan baik dan tidak terjadi kendala. Namun pada aspek kepemimpinan, pemasaran, legalitas usaha, dan perubahan pasar belum sepenuhnya dijalankan dengan baik dan masih masih memenuhi kendala serta kurangnya modal dan dukungan dari pemerintah.

Kedua, ketahanan ekonomi keluarga wirausaha Kampung Sanggrahan Pathuk adalah sebagai berikut: (1). Pada perhitungan pendapatan dan kebutuhan secara skala Likert menunjukkan ketahanan ekonomi di kategorikan tidak miskin. (2). Pada perkonversian pendapatan para wirausaha pemuda Kampung Sanggrahan Pathuk dengan menggunakan standar UMK disimpulkan tidak ada yang dikategorikan miskin. (3). Kontribusi rata-rata pendapatan dari wirausaha memberikan kontribusi yang sangat besar terhadap pemenuhan kebutuhan keluarga. (4). Pada perhitungan rata-rata pendapatan dan pengeluaran per kapita per rumah tangga menunjukkan tiap rumah tangga dikategrikan tidak miskin, dilihat juga dari selisih pendapatan dan pengeluaran per bulan.

Selanjutnya, direkomendasikan hal-hal sebagai berikut:

Pertama, pemasaran. Pemuda pemilik usaha pada koperasi SUMEKAR di Kampung Sanggrahan Pathuk hendaknya berusaha meningkatkan usahanya melalui (1). Inovasi produk yang lebih menarik minat calon konsumen, seperti kardus kemasan produk yang menarik, memberikan diskon harga di hari-hari tertentu. Ini karena segmentasi pasar di jaman sekarang sering menggunakan internet, sehingga pemuda lebih meningkatkan pemasaran dan promosi harga pada berbagai sosial media, seperti Twitter, Facebook, website, Path, Instagram dan lain sebagainya. (2). Melakukan kerjasama dengan tempat- tempat yang banyak dikunjungi orang seperti toko oleh-oleh, usaha pariwisata, daerah pusat perbelanjaan Malioboro. Kerjasama ini dalam bentuk pemberian kupon potongan harga kepada konsumen yang melakukan transaksi di tempat tersebut. Potongan harga berlaku untuk pembelian langsung di Kampung Sanggrahan Pathuk. (3). Memperluas lagi segmentasi pasar yang akan dijadikan sasaran pemasaran, sehingga perlu adanya staf marketing agar pemasaran yang dilakukan dapat maksimal.

Kedua, legalitas usaha. Pemuda pemilik usaha pada koperasi SUMEKAR di Kampung Sanggrahan hendaknya melegalkan produk usaha mereka sebagai strategi dalam mewujudkan wirausaha mandiri ,melalui MUI, BPOM, dan Surat Izin lainnya yang berkaitan dengan pendirian usaha. Justru jika pelegalan itu tidak diurus, nantinya pengusaha itu sendiri yang akan mendapatkan kesulitan dalam kegiatan usahanya. Selain merasa terancam dengan penertiban oleh pihak berwajib, mereka juga akan kesulitan mengembangkan usahanya menuju ke arah yang lebih baik.

Ketiga, kepemimpinan. Para pemuda hendaknya dapat menerapkan sistem manajerial usaha dengan cara selalu mengikuti seminar pelatihan kepemimpinan yang diselenggarakan pihak pemerintah, dan pihak swasta.

Keempat, modal dan dukungan pemerintah. Para pemuda hendaknya aktif menjalin kerjasama dengan pemerintah dan pihak swasta dalam usaha turut serta memperoleh bantuan modal untuk usaha.

Kelima, kebijakan harga. Koperasi SUMEKAR hendaknya mempertegas kebijakan aturan penetapan harga produk usaha para pelaku usaha, serta sering mengadakan evaluasi dan pertemuan terbuka dengan 
Lusmino Basia, John Suprihanto, dan Armaidy Armawi -- Strategi Pengembangan Wirausaha Pemuda Dalam Mewujudkan Wirausahawan Mandiri Dan Implikasinya Terhadap Ketahanan Ekonomi Keluarga (Studi Pada Koperasi Sumekar Di Kampung Sanggrahan Pathuk Kecamatan Ngampilan Kota Yogyakarta

para pelaku usaha Kampung Sanggrahan Pathuk sebagai strategi dalam membantu mengembangkan usaha. Koperasi SUMEKAR juga hendaknya memperbaiki peran sebagai mediator antara pemerintah dengan para pelaku usaha di Kampung Sanggrahan Pathuk.

Keenam, pemerintah. Terkait dengan perwujudan wirausaha muda mandiri, perlu kiranya menjadikan pengembangan kewirausahaan pemuda, sebagai landasan untuk merumuskan setiap kegiatan yang disusun, sehingga layanan kepemudaan dalam berwirausaha bisa lebih maksimal dan terarah. Pemerintah hendaknya mendorong tumbuh kembangnya wirausaha-warausaha muda yang mandiri.

\section{DAFTAR PUSTAKA}

Badan Pusat Statistik, 2007, Indikator Kesejahteraan Rakyat Di Indonesia, Jakarta: BPS , 2015, Konsumsi Pengeluaran Kota Yogyakarta, Jakarta: BPS

Drucker, Peter.F, 1979. Manajemen: Tugas, Tanggung jawab dan Praktek, Terjemahan, Jakarta: Penerbit PT Gramedia.

Euis, Sunarti, 2003, Mengasuh Dengan Hati Tantangan Yang Menyenangkan, Jakarta: Penerbit Elex Media Komputindo

Frinces, Heflin, 2004. Kewirausahaan dan Inovasi Bisnis, Cetakan Pertama, Yogyakarta: Penerbit Darusalam .

Geoffrey, Meredith, 2000, Kewirausahaan: Teori Dan Praktek, Jakarta: Pusaka Binaman Pressindo

Glueck William F, Jauch, Lawrence R. 2001. Manajemen Strategis dan Kebijakan Perusahaan, Jakarta: Erlangga.
Hendra. 1986. Perencanaan dan Pembangunan di Indonesia, Jakarta: Gramedia.

Kartasasmita, Ginandjar. 1996. Pembangunan Untuk Rakyat: Memadukan Pertumbuhan Dan Pemerataan, Jakarta: Pustaka CIDESINDO.

Lovelock, C.H. and L.K. Wright. 2002. Principles of Servis Marketing and Management. New Jersey: Pearson education. Inc.

Nasrun, M.A., 2010. Mengapa Banyak Sarjana yang Menganggur?, Suara Merdeka. 25 September, 2010

Priyono, Joko, \& Syarbini, Husin. 2014. Strategi Mengubah Usaha Kecil Minim Menjadi Kaya Miliaran. Solo: PT. Tiga Serangkai Pustaka Mandiri.

Setiadi, U.2008. "Suatu Pemikiran Mengenai Pendekatan Kembali Antara Dunia Pendidikan S1 Manajemen Dengan Dunia Kerja”. Prosiding Konferensi Merefleksi Domain Pendidikan Ekonomi dan Bisnis, Salatiga.

Sugiyono, 2010, Metode Penelitian Kuantitatif, Kualitatif, dan $R$ \& $D$, Bandung: CV. Alfabeta

Suryana, 2003, Kewirausahaan: Pedoman Praktis, Kiat, dan Proses Menuju Sukses, Jakarta: Salemba Empat

Tambunan, Tulus TH, 2009. UMKM diIndonesia. Jakarta: Ghalia Indonesia

Wibowo, Agus. 2011. Pendidikan Kewirausahaan (konsep dan strategi). Yogyakarta: Pustaka Pelajar.

World Bank, 2006, Making The New Indonesia Work For The Poor, Jakarta.

\section{Peraturan Perundangan}

Undang-Undang Republik Indonesia Nomor 5 Tahun 1999 Tentang Larangan 
Praktek Monopoli dan Persaingan Usaha Tidak Sehat

Undang-Undang Republik Indonesia Nomor 40 Tahun 2009 Tentang Kepemudaan Instruksi Presiden Nomor 4 tahun 1995 Tentang Gerakan Nasional
Memasyarakatkan dan Membudayakan Kewirausahaan

Surat Keputusan (SK) Gubernur DIY Nomor 252/Kep/2014 Tentang Upah Minimum Kabupaten/Kota (UMK) 2015 di DIY.

Peraturan Daerah Kota Yogyakarta, Nomor 2 Tahun 2015 Tentang Izin Gangguan. 